\title{
TÖRTÉNELEM A POLITIKA HÁTTERÉBEN (A RENDSZERVÁLTÁS UTÁNI MAGYARORSZÁG POLITIKAI RENDSZERE, VALAMINT 19-20. SZÁZADI ELÖZMÉNYEI)
}

\author{
Fazekas Csaba \\ egyetemi docens, Miskolci Egyetem, Alkalmazott Társadalomtudományok Intézete \\ 3515 Miskolc, Miskolc-Egyetemváros, e-mail: fazekas@uni-miskolc.hu
}

\begin{abstract}
Absztrakt
A cikk a „Történelem a politika hátterében” c., a „Fiatalodó és megújuló egyetem - Innovatív tudásváros" projekt támogatásával megvalósult kutatási program beszámolóját foglalja össze. A kutatási program két periódusra oszlott: 1. Az 1989-90-es rendszerváltás utáni magyar politikai rendszer egyes sajátosságai (közös kutatás Fekete Sándorral). 2. A magyar politikai rendszer 19-20. századi elözményei (saját kutatások). A cikk bemutatja a kutatási program legfontosabb területeit és eredményeit: önkormányzatiság és a politikai pártok rendszere a rendszerváltás utáni Magyarországon, a 19. századi liberalizmus és a két világháború közötti, ún. „,keresztény-nemzeti” ideológia öröksége.
\end{abstract}

Kulcsszavak: politikai pártok, politikai ideológiák, rendszerváltás Magyarországon, történelem és politika

\begin{abstract}
Paper contains a research report entitled "History in the Background of Politics" supported by "Younger and Renewing University - Innovative Knowledge City" project. The research period divided into two parts: 1. Specialties of the political system of Hungary after the 1989-90 transition (common research with Sándor Fekete) 2. Antecedents of the Hungarian political system from the $19^{\text {th }}$ and $20^{\text {th }}$ centuries (own researches). Paper presents the most important fields and results of the research projects: self-governments and political party structure of post-transition Hungary, the heritage of the $19^{\text {th }}$ century liberalism and the so-called "Christian nationalist" ideology of the interwar Hungary.
\end{abstract}

Keywords: political parties, political ideologies, transition in Hungary, history and politics

\section{Bevezetés}

A kutatási program keretében született legfontosabb tanulmányok felsorolását az Irodalom fejezetben foglaltuk össze. A kutatás legfontosabb célkitüzése az volt, hogy részben a rendszerváltás utáni magyar politikai rendszer egyes sajátos, jellemző vonásait elemezzük, másrészt - a teljesség igénye nélkül, markáns folyamatok kiemelésével - hozzájáruljunk egyes politikai jelenségek történelmi háttérbe való ágyazásához, az előzmények és ,áthallások” feltárásával és elemzésével.

Az összesen 21 publikált tanulmány között egy monográfia, 10 folyóiratban, 10 tanulmánykötetben megjelent terjedelmes dolgozat található, a publikációk mintegy fele (10 tanulmány) angolul, a továbbiak magyar nyelven kerültek publikálásra. Az idegen nyelvü és külföldi kiadóknál, periodikákban közzétett publikációk célja egyértelmüen a magyar történet- és politikatudományi kutatások eredményeinek külföldi megismertetése, a nemzetközi szakmai vérkeringésbe való bekapcsolásának elősegítése volt. Mindezek mellett a projekt segítségével valósítottunk meg egy nemzetközi (Egyesült Álla- 
mokban tartott), valamint öt magyarországi konferencia-részvételt és eredményeinkről előadás formájában való beszámolást. Szintén a projekt támogatásával készítettük el 2020 tavaszán a Miskolci Egyetem Bölcsészettudományi Karának kutatói almanachját, mely Bonarum Cultores Artium címmel a Szellem és Tudomány folyóirat egy magyar, illetve egy angol nyelvü különszámaként látott napvilágot.

\subsection{A kutatás elméleti alapjai}

A kutatási program elméleti alapjainak kialakításakor abból a - részben talán közismert, részben talán részletesebb indoklásra szoruló - jelenségből indultunk ki, miszerint a magyar politika világa az 1990es évektől meglehetősen historizáló jellegü volt, és napjainkban is az. Vagyis erőteljesen jelen van a politikai pártok kommunikációjában, a közpolitikán belül (nem csupán az emlékezetpolitikában) a történelmi múltra való hivatkozás, a történelmi háttér eltérő politikai álláspontokat hitelesítő, legimitáló szerepe. Ezért részben arra törekedtünk, hogy konkrét esettanulmányokon keresztül bemutassuk a rendszerváltás utáni magyar politika világának sajátosságait (a pártrendszer, illetve az önkormányzatiság jelenségeit), valamint 19-20. századi esettanulmányokon keresztül mutassuk be a történelmi múlt politikaformáló, továbbá legitimációs jelenségeit. (Előbbiek a szerző és Fekete Sándor közös kutatásainak eredményeiben, utóbbi különösen e sorok írójának kutatásaiban formálódott magyar és angol nyelvü tanulmányokká.) Lényegében azt a kettős célt tűztük ki magunk elé, hogy egyrészt hogyan regisztrálhatjuk a kortárs magyar politika egyes meghatározó jelenségeit, valamint hogyan ismerhetjük fel a 19-20. századi magyar történelemben mindezek előzményeit.

\section{A rendszerváltás utáni magyar politika egyes elemei}

A magyar demokratikus jogállam elmúlt harminc évének történetének sajátosságai közül különös figyelmet fordítottunk a politikai pártok rendszerének változásaira. A magyarországi rendszerváltás sajátossága volt annak békés, ,tárgyalásos” jellege, eltérően más közép-kelet-európai államoktól a folyamat nem forradalmi úton, hanem egy elnyúló, politikai alkufolyamatokból építkező átmenetként valósult meg, melynek egyik szereplöje az átalakuló, majd megszünő állampárt tekinthető.

Jellemző sajátosságként vehető figyelembe, hogy a pártrendszer demokratizálódása, az egypárti struktúra többpártivá alakulása jóval az első, 1990 tavaszán tartott szabad választások előtt megkezdődött, részben új, értékorientált politikai pártok létrejöttével (például a konzervatív irányultságú MDF, a liberális SZDSZ és liberálisként indult FIDESZ), valamint a történelmi gyökerü pártok (FKGP, KDNP) újjáalakulásával. 1990-től mintegy másfél évtizeden keresztül a pártrendszert hárompólusú, leginkább szabályos (egyenlő oldalú) háromszögként írhatjuk le, melynek három pólusa is különböző pártok között tagolódott: volt egy jobboldali-konzervatív pólus (MDF, FKGP, KDNP, az 1990-es évek közepétől a Fidesz), egy liberális pólus (SZDSZ, illetve eleinte a Fidesz) és egy baloldaliszociáldemokrata pólus, melyet elsősorban a rendszerváltás előtt létrejött MSZP testesített meg. A pártrendszer alapvetően tagolt, váltógazdálkodásra alkalmas, versengő pártok által megvalósított struktúra volt, természetes összefüggésben az 1989. évi jogállami alkotmány, valamint a - kétfordulós, kombinált, de a listás mandátumokat előtérbe helyező - választási rendszer által teremtett helyzettel. Ebben a rendszerben a jobb- és baloldali szélsőségek nem, vagy kevéssé befolyásolták a pártpolitikai folyamatokat. A 2006-os választások utáni események feloldották ezt a pártrendszert, s a 2010-2011es rendszerváltó folyamat következtében „centrális erőtér” jött létre (domináns jobboldali-nemzeti pártszövetséggel, a Fidesz-KDNP-vel), a markáns liberális formáció eltünt, a pártrendszer inkább egy egyenlö szárú, tompaszögủ háromszöggel jellemezhető. (A markáns és túlsúlyos kormpánypártok csúcsa mellett a másik két pólust egy sokfelé tagolt, de vékony baloldali-liberális pólus, illetve egy 
hasonló nagyságú szélsőjobboldali pólust különíthetünk el a 2010-es évek végéig.) (Ld. [2], [3], [4], [6], [10])

A másik kutatási irány az önkormányzatiság jelenségének értelmezése jelentette. (Ld. [5], [7], [9]) A rendszerváltás időszakában született helyhatósági törvény széles körben ruházta fel a helyi önkormányzatokat feladatok ellátásával, a régi tanácsrendszert meghaladó jogszabály nem egy központi akaratot végrehajtó, hanem a helyi közösségek önigazgatását és érdeképviseletét lehetővé tevő rendszert alakított ki. Az önkormányzatok választását biztosító egyes jogszabályok változása (például 1994-ben az egyfordulós, közvetlen polgármester-választást kialakító rendszer) után a legnagyobb horderejü változásokat az önkormányzatokról szóló 2011. évi CLXXXIX. törvény valósította meg, jelentősen átalakítva a helyi képviseletek mozgásterét. (További, politikatörténethez és a politikai gondolkodás-történethez kapcsolódó esettanulmányainkra: [1], [8])

\section{Történelem és politika}

A magyarországi politikatörténet egyik sokat elemzett, ugyanakkor még mindig (és vélhetően még sokáig) inspiráló témaköre a modern politikai folyamatok genezisének tekinthető reformkor időszaka. A „régi”, gyakran feudálisnak nevezett politikai és társadalmi rendszert leváltani készülő időszak liberális, nemzeti és ellenzéki politikájának bázisa a vármegye volt. Az ennek színterén megfogalmazódó álláspontok, valamint a kor „kisembereinek” gondolkodásában, nyelvhasználatában stb. megfigyelhet” jelenségek fontos adalékai a magyarországi liberalizmus - napjainkra is sokrétú hatást gyakorló - emlékezetének. (Ld. [19], [20], [21])

A kutatási projekt időszaka éppen egybeesett a Magyarország történetében fordulatos és sorsfordító 1918-1920-as évek 100. évfordulója. Az évforduló által kínált lehetőségeket kihasználva az első magyarországi totalitárius rendszer(kísérlet), a Tanácsköztársaság egyházpolitikai intézményrendszerét tettük elemzésünk tárgyává. (Ld. [15], [16])

Részben az évfordulónak köszönhető, hogy a Horthy-rendszer születése kapcsán előtérbe került a „keresztény-nemzeti” eszmerendszer, a két világháború közötti Magyarország napjainkban is egyre gyakrabban hivatkozott ideológiai konstrukciója. Ennek egyik teoretikus megfogalmazója, Prohászka Ottokár (1858-1927) székesfehérvári püspök közszereplései kapcsán próbáltuk feltérképezni az ideológia legfontosabb elemeit és hatásait. Prohászka kapcsán fogalmaztuk meg a „történeti közszereplést”, mint lehetséges kutatási irányt, vagyis azt a kérdést tettük fel, hogy vissza lehet-e vetíteni a „közszereplés” fogalmát és tanulmányozását történelmi időszakokba. A hagyományos értelemben vett történeti életrajzok ugyanis magára a történeti személyekre koncentrálnak. A „történeti közszereplés” kutatása azonban a személyen keresztül arra a történeti-politikai miliőre kíváncsi, amelyben az illető tevékenykedett, lényege, hogy arra irányul: milyen hatással van a politikai döntéshozatal folyamataira egy, a nyilvános térben gyakran megjelenő személyiség, véleményformáló értelmiségi illető.

A már életében is „Magyarország apostolának és tanítómesterének” nevezett Prohászka a Horthyrendszer kialakulásának időszakában feltünően aktív közszereplőnek számított, egyházi (püspöki) tevékenységének ellátása mellett gyakori szónoka volt társadalmi és politikai szervezetek rendezvényeinek, nagygyüléseinek, rengeteg publicisztikát írt, gyakran adott interjút a sajtónak. A püspök a Horthy-korszak elején tudatosan helyezkedett az elméleti útmutató szerepkörébe, de megpróbálkozott a gyakorlati politizálással is. (1920-22 között nemzetgyülési képviselö, néhány hónapig az egységes kormánypárt elnöke volt.) A sokak által magukévá tett, mérsékelt és radikális formájában egyaránt vallott, jobboldali-konzervatív „keresztény-nemzeti” eszmerendszer lényegét egy új antiliberális nemzetfogalom jelentette, miszerint az ,igazi”, ,jó” magyarok valamely keresztény történelmi egyház hívei és fordítva. Prohászka mindezt összekapcsolta egy új történelem-értelmezéssel (a dualizmus 
korában kicsúcsosodó nemzeti hanyatlás víziójával, az 1918. október 31-gyel kezdődő korszakok teljes elutasításával), valamint a magyar nép igazi magyarokra és „,idegenekre” való felosztásával, utóbbi lényegét a zsidóellenességben jelölve meg. (Prohászka és a korai Horthy-rendszer antiszemitizmusa az egyik leginkább vitatott emlékezetpolitikai kérdés is egyben.) (Összefoglaló monográfiánk: [11], ennek kritikájára készült részletes koncepció-magyarázat: [12], vonatkozó részletes esettanulmányok: [13], [14] Az antiszemitizmus-történet átfogó összefoglalására tett kísérlet: [17], [18])

\section{Köszönetnyilvánítás}

A cikkben ismertetett kutató munka az EFOP-3.6.1-16-2016-00011 jelü „Fiatalodó és Megújuló Egyetem - Innovatív Tudásváros - a Miskolci Egyetem intelligens szakosodást szolgáló intézményi fejlesztése" projekt részeként - a Széchenyi 2020 keretében - az Európai Unió támogatásával, az Európai Szociális Alap társfinanszírozásával valósult meg.

\section{Irodalom}

[1] Fazekas, Cs., Fekete, S.: Iszlám-kép és történelemtanitás Magyarországon, In: 100 éves a magyar iszlámtörvény, Szerk. Köbel, Sz., Tóth, J. Z. Károli Gáspár Református Egyetem, Államés Jogtudományi Kar, Budapest, Acta Caroliensia Conventorum Scientiarium IuridicoPoliticarum; XX., pp. 78-87., 2017.

[2] Fazekas, Cs., Fekete, S.: Party system in Hungary, In: Contemporary Political Parties and Party Systems in the Visegrad Group Countries, ed. Kancik-Kołtun, E. Marie Curie-Skłodowska University Press, Lublin, pp. 133-146., 2018.

[3] Fazekas, Cs., Fekete, S.: Contemporary parlamentary political parties in Hungary, In: Contemporary Political Parties and Party Systems in the Visegrad Group Countries, ed. Kancik-Kołtun, E., Marie Curie-Skłodowska University Press, Lublin, pp. 147-173., 2018.

[4] Fazekas, Cs., Fekete, S.: Historical outline of the development of the hungarian party system, Review of History and Political Science, 6 No. 2. (2018) pp. 36-46.

https://doi.org/10.15640/rhps.v6n2a5

[5] Fazekas, Cs., Fekete, S.: The characteristics of the hungarian self-government, In: Slovensko Európa - Svet: Zborník príspevkov, eds. Dvorský, T., Laczkó, L., Lörincová, K. Univerzita Pavla Jozefa Šafárika v Košiciach, Košice, pp. 116-135., 2019.

[6] Fazekas, Cs., Fekete, S.: Theories and practices concerning legitimisation crises, Review of History and Political Science, 2 (2017) pp. 52-55.

[7] Fazekas, Cs., Fekete, S.: The effect of the Amendments of Hungary's Fundamental Law on the Sovereignty of local self-governments, In: Aktuálne otázkyteórie a praxe politiky a medzinárodných vzt’ahov, eds. Babušík Adamčíková L., Koscelanský, G.; Petriková M. Univerzita Pavla Jozefa Safárika v Kosiciach, Košice, pp. 212-225., 2018.

[8] Fazekas, Cs., Fekete, S.: Two concept of social contract: Apel and Buchanan, Rocznik Politologiczny - Political Science Annual, 13 No. 4 (2017) pp. 21-27.

[9] Fazekas, Cs., Fekete, S.: Change of the local self-governments' sovereignty in Hungary, Slovak Journal of Public Policy and Public Administration, 4 No. 1 (2017) pp. 20-29.

[10] Fazekas Cs.: Rise and fall of beer lovers' parties in East-Central Europe: Party History and general lessons, REGION: Regional Studies of Russia, Eastern Europe, and Central Asia, 2021. (megjelenés elött)

[11] Fazekas Cs.: Válogatás Prohászka Ottokár közszerepléseiböl, 1919-1927. (Cikkek, interjúk, beszédek) Bíbor Kiadó, Miskolc, 2019. ISBN 978-615-5536-76-2. 415 old. 
[12] Fazekas Cs.: Válasz Mózessy Gergelynek, Egyháztörténeti Szemle, 21 No. 1. (2020) pp. 119133.

[13] Fazekas Cs.: Prohászka Ottokár és az Ébredö Magyarok Egyesülete, In: Tanulmányok a magyarországi zsidóság történetéből, szerk. Gecsényi, L., Fazekas, Cs., Milton Friedman Egyetem, Budapest, 2019. pp. 140-163.

[14] Fazekas Cs.: Keresztény kultúra és közszereplés Prohászka Ottokár , hattyúdalaiban”, In: Tudomány, oktatás, kultúra a két világháború közötti Magyarországon, szerk. Pelesz, M., Radnóti, N. Szegedi Öröksége Alapítvány, Szeged, 2019. pp. 228-277.

[15] Fazekas Cs.: A Tanácsköztársaság „Vallásügyi Likvidáló Hivatala”, In: „....minden édenek neve vad poklokat büvöl”. A Magyarországi Tanácsköztársaság. Szerk.: Ligeti, D., Vörös, B., Országház Könyvkiadó, Budapest, 2020. pp. 161-172.

[16] Fazekas Cs.: A „likvidáló hivatal”, Megjegyzések a Tanácsköztársaság egyházpolitikájának intézményi hátteréről, In: A Tanácsköztársaság és az egyházak. Egyházpolitika, keresztényüldözés, egyházi útkeresés. szerk. Fejérdy, A., Szent István Társulat, Budapest, 2020. pp. 102113.

[17] Fazekas Cs.: A keresztény egyházak és az antiszemitizmus kapcsolatainak vázlata a 19-20. századi Magyarországon, Szellem és Tudomány, 11 Különszám, (2020) pp. 144-152.

[18] Fazekas, Cs.: Outline of the Connections between the Christian Churches and the AntiSemitism in 19th-20th century Hungary, Szellem és Tudomány, 11 Supplement, (2020) pp. 134-143.

[19] Fazekas Cs.: Borsod vármegyei követek jelentései 1848 márciusában, Szülőföldünk, 39 No. 38-39. (2020) pp. 50-57. https://doi.org/10.1097/01.NURSE.0000654520.40980.be

[20] Fazekas Cs.: Reformkori viták a magyar nyelvü hónapnevekröl, Publicationes Universitatis Miskolcinensis. Sectio philosophica, 24 No. 1. (2020) pp. 123-140.

[21] Fazekas Cs.: Szilágyi Lajos emlékirata a 19. századi Erdélyröl, In: Areopolisz, XIX. szerk. Kolumbán, Zs., Róth, A. L. Areopolisz Egyesület, Székelyudvarhely, 2020. pp. 53-96. 